\title{
SISTEM INFORMASI EKSEKUTIF MANAJEMEN DATA KINERJA DOSEN PRODI TEKNIK INFORMATIKA STMIK NURDIN HAMZAH
}

\author{
Sukma Puspitorini ${ }^{1)}$, Reny Wahyuning Astuti' ${ }^{2)}$, dan Fikri Al Hakim ${ }^{3)}$ \\ 1,2,3 Prodi Teknik Informatika STMIK Nurdin Hamzah \\ 1,2,3 J1. Kolonel Abunjani, Sipin-Kota Jambi, 36126 \\ E-mail : sukm4pit@gmail.com ${ }^{1)}$,r3ny4stuti@gmail.com ${ }^{2)}$, fikrialhakim54@gmail.com ${ }^{3)}$
}

\begin{abstract}
ABSTRAK
Pengolahan data kinerja dosen merupakan salah satu bagian dalam proses penyusunan Borang 3A pada Akreditasi Program Studi yang dilakukan secara periodik oleh Perguruan tinggi baik negeri maupun swasta . Hal tersebut juga dilakukan oleh Prodi Teknik Informatika (Prodi TI) STMIK Nurdin Hamzah (STMIK NH) setiap semester sebagai bagian dari proses manajemen berkas data tridharma dosen yang meliputi Pengajaran, Penelitian, dan Pengabdian Kepada Masyarakat. Selama ini proses pengolahan data kinerja dosen pada Prodi TI STMIK NH dilakukan tanpa menggunakan suatu sistem khusus yang terkomputerisasi sehingga mengurangi efisiensi proses pengolahan data kinerja dosen secara keseluruhan. Sistem Informasi Eksekutif Pengolahan Data Kinerja Dosen Program Studi Teknik Informatika STMIK Nurdin Hamzah merupakan sebuah sistem informasi yang dibangun berbasis web yang dikembangkan dengan tujuan untuk mempermudah proses pengolahan data maupun berkas terkait kinerja dosen Prodi TI secara keseluruhan dan mengatasi kekurangan yang ada pada sistem yang selama ini masih berjalan. Sistem baru yang dikembangkan akan diimplementasikan dalam bentuk aplikasi berbasis web dan dibangun dengan menggunakan bahasa pemrograman PHP, perangkat lunak manajemen basis data MySQL, serta framework CodeIgniter dan Bootstrap. Data input meliputi data diri dosen, data aktivitas Tri Dharma dosen, dan data penunjang lainnya. Data keluaran (output) yang dihasilkan dari penggunaan aplikasi pengolahan data kinerja dosen Prodi TI STMIK Nurdin Hamzah yaitu informasi terkait kinerja dosen yang disajikan dalam bentuk tabel, grafik dan laporan dalam bentuk teks yang disusun berdasarkan data dan berkas penunjang yang telah dikumpulkan oleh setiap dosen. Adapun laporan yang dihasilkan meliputi laporan kinerja individual dosen dan laporan kinerja seluruh dosen Prodi TI. Hasil dari penelitian ini menunjukkan bahwa sistem yang terkomputerisasi dapat meningkatkan efisiensi dan efektifitas pengolahan data kinerja dosen serta proses penyusunan borang akreditasi Prodi TI secara keseluruhan.
\end{abstract}

Kata Kunci: Data Kinerja Dosen, Sistem Informasi Eksekutif, Teknik Informatika, STMIK Nurdin Hamzah, Web

\section{PENDAHULUAN}

Data merupakan aspek penting dalam sebuah organisasi baik perusahaan, lembaga, maupun instansi lainnya. Data dibutuhkan untuk keperluan perencanaan, pelaksanaan/penentuan kebijakan, pemantauan maupun evaluasi kegiatan.. Data sendiri merupakan kenyataan yang menggambarkan suatu kejadian serta merupakan suatu kesatuan yang nyata, dan merupakan bentuk yang masih mentah sehingga perlu diolah lebih lanjut melalui suatu model untuk menghasilkan informasi. (Sutabri. 2012). Oleh karena itu penting untuk dilakukan pengumpulan dan pengolahan data guna menunjang kegiatan tersebut.

Salah satu contoh kegiatan pengolahan data dapat ditemukan pada Sekolah Tinggi Manajemen Informatika dan Komputer (STMIK) Nurdin Hamzah Jambi, dimana secara periodik dilakukan pengolahan data untuk berbagai keperluan, salah satunya adalah pengolahan data kinerja dosen yang merupakan bagian dari kegiatan penyusunan borang akreditasi Program Studi (untuk selanjutnya disebut Prodi). Hal tersebut juga dilakukan oleh Prodi Teknik Informatika (Prodi TI) STMIK Nurdin
Hamzah (STMIK NH). Akreditasi merupakan salah satu bentuk penilaian (evaluasi) mutu dan kelayakan institusi perguruan tinggi atau program studi yang dilakukan oleh organisasi atau badan mandiri di luar perguruan tinggi (Widiastuti \& Susanto. 2014).

Ada banyak sekali komponen yang harus diolah dalam kegiatan penyusunan borang akreditasi Prodi ini, salah satunya adalah kinerja dosen. Komponen ini sendiri terdiri dari banyak sekali data kuantitatif yang harus disiapkan oleh setiap dosen Prodi TI untuk kemudian dikumpulkan dan dilampirkan dalam buku 3A borang akreditasi Prodi TI bersama dengan berbagai data dari komponen lain dalam borang akreditasi tersebut.

Kinerja dosen merupakan salah satu faktor penentu keberhasilan proses belajar mengajar di perguruan tinggi dimana terdapat hubungan yang erat antar kinerja perseorangan dengan kinerja perusahaan. Sehingga dosen sebagai salah satu elemen perguruan tinggi, dalam kaitannya dengan hal ini, peningkatan kinerjanya juga dapat meningkatkan kinerja perguruan tinggi (Permanasari, Setyaningrum, dan Sundari. 2014). 
Selama ini proses pengolahan data kinerja dosen Prodi TI STMIK Nurdin Hamzah dilakukan dengan cara menginput data-data yang diperlukan satu persatu ke dalam software Microsoft Excel oleh admin yang bertugas dan berkas-berkas tambahan yang telah diserahkan oleh setiap dosen disimpan begitu saja di komputer tanpa adanya data center atau penyimpanan data yang terpusat.

Proses pengolahan data yang masih dilakukan dengan cara yang telah dijelaskan di atas tentunya memiliki beberapa kekurangan, antara lain: 1) Kurangnya efisiensi dalam pengumpulan atau pembaruan data karena setiap dosen harus terlebih dahulu mengumpulkan data dan berkas yang dibutuhkan secara individu untuk kemudian diserahkan kepada admin; 2) Kerap terjadinya pengolahan data yang berulang-ulang akibat tidak adanya data center yang dapat dikelola secara periodik; 3) Rentan terjadinya kehilangan data dan berkas yang telah terkumpul karena data dan berkas hanya disimpan tanpa adanya pencadangan (backup) di dalam komputer yang bisa saja mengalami kerusakan; 4) Rentan terjadinya kesalahan dalam penginputan data dosen oleh admin karena tidak dikontrol secara langsung oleh dosen yang bersangkutan; dan 5) Sulitnya melakukan pengecekan data secara keseluruhan karena data disimpan tanpa adanya struktur yang rapi dan teratur.

Untuk mengatasi permasalahan tersebut, maka perlu dibangun suatu sistem yang dapat digunakan untuk mendokumentasikan dan mengelola data berkas dosen. Tujuan dari penelitian ini adalah membangun suatu Sistem Informasi Eksekutif yang mampu mempermudah proses manajemen dan pengolahan data kinerja dosen yang meliputi data diri dosen, data aktivitas tri dharma dosen, dan data penunjang lainnya secara lebih efisien, efektif, komprehensif, dan aman.

\section{RUANG LINGKUP}

Sistem informasi pengolahan data kinerja dosen ini difokuskan pada permasalahan bagaimana membangun Sistem Informasi Eksekutif (SIE) Manajemen Pengolahan Data Kinerja Dosen Program Studi Teknik Informatika STMIK Nurdin Hamzah Jambi dengan menggunakan bahasa pemrograman PHP dan perangkat lunak manajemen database MySQL. Hasil penelitian yang diperoleh adalah suatu sistem terkomputerisasi berbasis web yang berisi berbagai form pengisian data serta halaman informasi eksekutif berupa dashboard yang menampilkan rangkuman informasi kinerja dosen dalam bentuk grafis dan laporan kinerja yang dapat digunakan untuk mempermudah manajemen pengolahan data kinerja dosen Prodi TI STMIK Nurdin Hamzah Jambi.

\section{BAHAN DAN METODE}

Berikut disajikan kajian teori dan metodologi penelitian ini

\subsection{Sistem Informasi Eksekutif (SIE)}

Menurut Kenneth dan Jane (2007), Sistem informasi secara teknis dapat didefinisikan sebagai sekumpulan komponen yang saling berhubungan, mengumpulkan atau mendapatkan, memproses, menyimpan, dan mendistribusikan informasi untuk menunjang pengambilan keputusan dan pengawasan dalam suatu organisasi (Amin, Puspitorini, Purnama, 2017). Sistem informasi memberikan nilai tambah terhadap proses, produksi, kualitas, manajemen, pengambilan keputusan, dan pemecahan masalah serta keunggulan kompetitif yang tentu saja sangat berguna bagi kegiatan bisnis (Pradana, 2016).

Sistem Informasi Eksekutif adalah salah satu tipe sistem informasi berbasis komputer yang ditujukan untuk memfasilitasi kebutuhan informasi yang berkaitan dengan tercapainya tujuan suatu organisasi bagi eksekutif (Achmad, 2018). Sistem Informasi Eksekutif (SIE) menurut McLeod (2001) merupakan suatu sistem yang khusus dirancang bagi manajer tingkat perencanaan strategis yang menyediakan informasi bagi eksekutif mengenai kinerja keseluruhan perusahaan dimana informasi dapat diambil dengan mudah dan dalam berbagai tingkat rincian dan ditampilkan dengan bentuk grafik, tabel, atau narasi (Bakhri \& Nuryamin, 2018). Sistem informasi eksekutif (Executive Information System / EIS) juga didefinisikan sebagai jenis sistem informasi manajemen yang dimaksudkan untuk memfasilitasi dan mendukung kebutuhan informasi dan pengambilan keputusan para eksekutif senior dengan menyediakan akses mudah ke informasi internal dan eksternal yang relevan untuk memenuhi tujuan strategis organisasi (Mulia, Komara, Putra, Mulyanto, \& Subarkah, 2018).

\subsection{Pengolahan Data}

Menurut Tata Sutabri, pengolahan data adalah suatu proses menerima data sebagai masukan (input), memproses (processing) menggunakan proses tertentu, dan mengeluarkan hasil proses data tersebut dalam bentuk informasi (output) (Mahyuni, dkk., 2014).

George R. Terry Ph.D menyatakan, pengolahan data adalah serangkaian operasi atas informasi yang direncanakan guna mencapai tujuan atau hasil yang diinginkan. Ada 8 unsur pokok pengolahan data, yaitu membaca, menulis atau mengetik, mencatat atau mencetak, menyortir, menyampaikan atau memindahkan, menghitung, membandingkan, dan menyimpan (Hutahaean, 2015).

\subsection{Kinerja Dosen}

Kata kinerja (performance) dalam konteks tugas sama dengan prestasi kerja. Pengertian kinerja dapat diartikan sebagai penampilan hasil karya personel baik kuantitas maupun kualitas dalam suatu organisasi. Sedangkan Payman Simanjuntak mengemukakan kinerja adalah tingkat pencapaian hasil dalam rangka mewujudkan tujuan perusahaan. Menurut Mangkunegara 
prestasi kerja berasal dari kata job performance atau actual performance yaitu hasil kerja secara kualitas yang dicapai oleh seorang pegawai dalam melaksanakan tugasnya dengan tanggung jawab yang diberikan kepadanya ((Permanasari, Setyaningrum, dan Sundari. 2014). Kinerja dosen merupakan salah satu faktor penentu keberhasilan proses belajar mengajar di perguruan tinggi. Praswirosentono dalam Anung Pramudyo (2010) menyatakan bahwa terdapat hubungan yang erat antar kinerja perseorangan dengan kinerja perusahaan (Permanasari, dkk., 2014)

\subsection{Kerangka Kerja Penelitian}

Untuk membantu dalam penyusunan penelitian ini, maka perlu adanya susunan kerangka kerja (framework). Kerangka kerja ini merupakan langkah-langkah yang akan dilakukan dalam penyelesaian masalah yang akan dibahas. Kerangka kerja ini terdiri dari beberapa tahapan. Tahap pengumpulan data dan informasi dilakukan untuk mengetahui proses pengolahan data kinerja dosen yang rutin dilakukan selama ini oleh Prodi TI STMIK NH. Hasil yang didapatkan dari tahap ini antara lain: (a) Data dan informasi terkait berkas kinerja dosen yang dibutuhkan sebagaimana yang telah ditetapkan di dalam buku 3A borang akreditasi; (b) Proses kerja yang terdiri dari tahapan pengolahan data kinerja dosen; (c) Pihak yang terlibat dalam proses pengolahan data kinerja dosen; (d) Waktu/periode pengolahan data kinerja dosen; dan (e) Hasil yang ingin dicapai dari kegiatan pengolahan data kinerja dosen Prodi TI ini. Adapun tahap analisis sistem pengolahan data kinerja dosen yang sedang berjalan dilakukan untuk mengidentifikasi masalah pada sistem yang sedang berjalan untuk menemukan permasalahan yang terjadi pada proses pengolahan data kinerja dosen Prodi TI STMIK NH yang berjalan selama ini sehingga peneliti dapat mencari solusi dari permasalahan tersebut. Selanjutnya, tahap pengembangan aplikasi pengolahan data kinerja dosen Prodi TI membagi tahapan dalam 3 proses yaitu : (a) Perancangan Database, Antarmuka dan Algoritma Aplikasi yang merupakan tahap awal pembangunan SIE, mulai dari perancangan tabel dan database hingga perancangan wireframe untuk tampilan antarmuka aplikasi, (b) Implementasi Hasil Perancangan ke dalam Bentuk Aplikasi Berbasis Web. Apabila perancangan sudah dirasa sesuai dengan analisis kebutuhan sistem. Pada proses ini dilakukan penulisan source code menggunakan HTML, CSS, Javascript dan PHP. Tahap pengujian dan validasi aplikasi bertujuan untuk mengetahui apakah aplikasi sudah berfungsi sesuai harapan, dan jika ternyata terdapat kesalahan sistem atau bug, maka penyebabnya bisa segera diketahui untuk kemudian diperbaiki. Setelah dilakukan pengujian dan validasi, maka tahap akhir adalah tahap perbaikan aplikasi yang berujuan untuk memperbaiki dan menyempurnakan aplikasi agar nantinya benar-benar bisa berfungsi sesuai harapan. Setelah aplikasi diperbaiki, maka harus kembali dilakukan pengujian untuk mengetahui apakah masih ditemukan kesalahan.

\subsection{Kebutuhan Input Sistem}

Sistem Informasi Eksekutif pengolahan data kinerja dosen Prodi Teknik Informatika (TI) memerlukan input antara lain:

1. Data login pengguna agar bisa mengakses aplikasi. Adapun data login untuk pengguna terdiri atas NIDN dan password

2. Data terkait kinerja dosen Prodi TI sesuai dengan panduan yang tertera pada buku 3A borang akreditasi Prodi. Data ini terdiri atas data pribadi dosen serta data kegiatan akademik dosen, antara lain:

1) Data dosen tetap dan tidak tetap

2) Data aktivitas dosen tetap

3) Data aktivitas mengajar dosen tetap dan tidak tetap

4) Data peningkatan kemampuan dosen tetap melalui tugas belajar

5) Data kegiatan dosen tetap

6) Data pencapaian prestasi/reputasi dosen

7) Data keikutsertaan dosen tetap dalam organisasi keilmuan/profesi

8) Data dosen pembimbing akademik dan pembimbing skripsi

9) Data kegiatan penelitian dan pengabdian kepada masyarakat (PKM)

10) Data artikel ilmiah/karya ilmiah/karya seni/buku oleh dosen

3. Berkas pelengkap data kinerja dosen dalam bentuk softcopy dengan format pdf atau word, yaitu:

1) Scan ijazah dan sertifikat pendidik dosen tetap dan tidak tetap

2) Softcopy dokumen bukti kegiatan dosen tetap dalam seminar ilmiah/ lokakarya/ penataran/ workshop/ pagelaran/ pameran/ peragaan

3) Softcopy dokumen bukti keikutsertaan dosen tetap dalam organisasi keilmuan/profesi

4) Softcopy dokumen bukti pencapaian prestasi/reputasi dosen

5) Softcopy dokumen laporan penelitian

6) Softcopy dokumen laporan hasil pelayanan/pengabdian kepada masyarakat

7) Softcopy artikel ilmiah/karya ilmiah/karya seni/buku

\subsection{Kebutuhan Proses Sistem}

Kebutuhan proses dalam aplikasi pengolahan data kinerja dosen Prodi TI STMIK Nurdin Hamzah antara lain:

1. Proses validasi data login pengguna

2. Proses penginputan dan penyimpanan data terkait kinerja dosen serta softcopy berkas pelengkap kegiatan dosen ke dalam databasel 
3. Proses penyajian informasi terkait kinerja dosen dalam bentuk tabel data dan halaman informasi eksekutif berisi infografis terkait kinerja dosen

4. Proses pembuatan laporan kinerja dosen

\subsection{Kebutuhan Output Sistem}

Data keluaran (output) yang dihasilkan dari penggunaan aplikasi pengolahan data kinerja dosen Prodi TI STMIK Nurdin Hamzah yaitu informasi terkait kinerja dosen yang disajikan dalam bentuk tabel, grafik, dan laporan yang disusun berdasarkan data dan berkas penunjang yang telah dikumpulkan oleh setiap dosen. Adapun laporan yang dihasilkan meliputi laporan kinerja individual dosen dan laporan kinerja seluruh dosen Prodi TI. Laporan dapat dicetak dalam format pdf maupun dalam format .xls

\subsection{Perancangan Sistem}

Metode perancangan yang digunakan untuk aplikasi web ini menggunakan metode pendekatan terstruktur dengan menggunakan diagram arus data (Data Flow
Diagram). Gambar 2 adalah diagram konteks yang menggambarkan alur data dari sistem yang akan dibangun secara umum. Pada gambar diatas dapat dilihat bahwa terdapat 3 entity yang terlibat dalam proses yaitu administrator, dosen, dan ketua prodi (kaprodi). Ketiga entity ini dapat berperan sebagai sumber data maupun penerima data/informasi. Selain itu terdapat 6 data flow pada diagram konteks di atas, yang terdiri dari 3 aliran data yang masuk ke proses (input data) dan 3 aliran data yang keluar dari proses (output data). Pada diagram konteks tersebut dapat dilihat bahwa dosen dan kaprodi memiliki hak akses terbatas dimana dosen hanya dapat melihat rangkuman informasi eksekutif kinerja dosen sendiri namun diijinkan oleh sistem untuk melakukan edit atau update data aktivitas dosen. Sedangkan Kaprodi dapat melihat rangkuman informasi eksekutif seluruh dosen namun tidak diperkenankan untuk melakukan edit atau update data dosen.

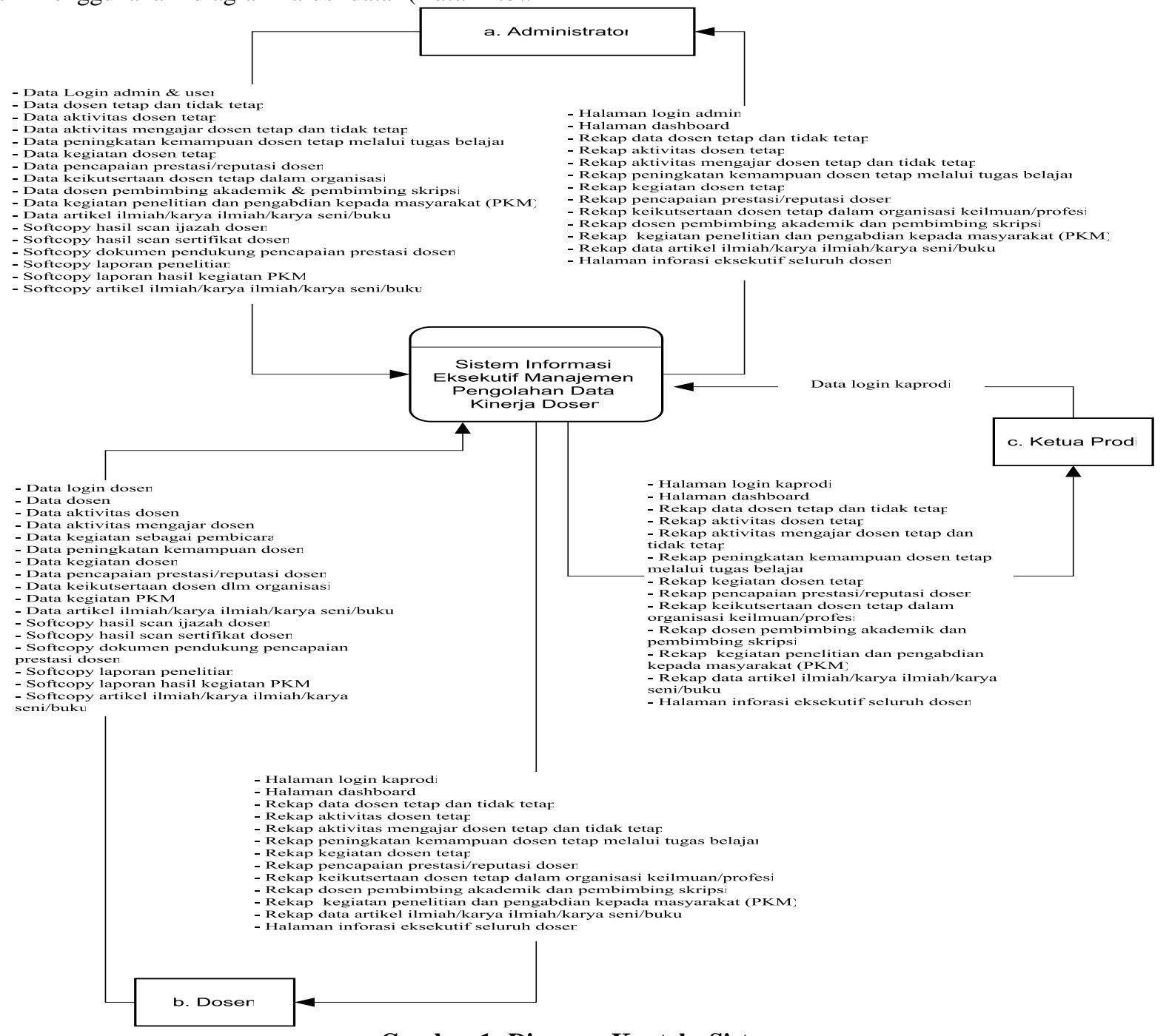

Gambar 1. Diagram Konteks Sistem 
Selanjutnya diagram konteks akan dipecah lagi menjadi beberapa proses turunan dalam DFD Level 0. Pada DFD Level 0 ini juga menggambarkan aliran data dan media penyimpanan (storage) utama di dalam sistem. sebagaimana ditunjukkan pada Gambar 3. DFD level 0 di atas merupakan pengembangan dari diagram konteks sebelumnya dan menggambarkan secara lebih rinci bagaimana sistem yang sedang dikembangkan akan berjalan. Subproses yang lebih rinci dari DFD Level 0 digambarkan dalam DFD Level 1 pada Gambar 4. Pada DFD Level 1 ini terdapat 4 subproses turunan yaitu :
1. Proses 1 : Proses login

2. Proses 2 : Proses olah data admin dan user.

3. Proses 3 : Proses Olah data dan berkas pelengkap data kinerja dosen

4. Proses 4 : Proses rekap data dan berkas pelengkap data kinerja dosen

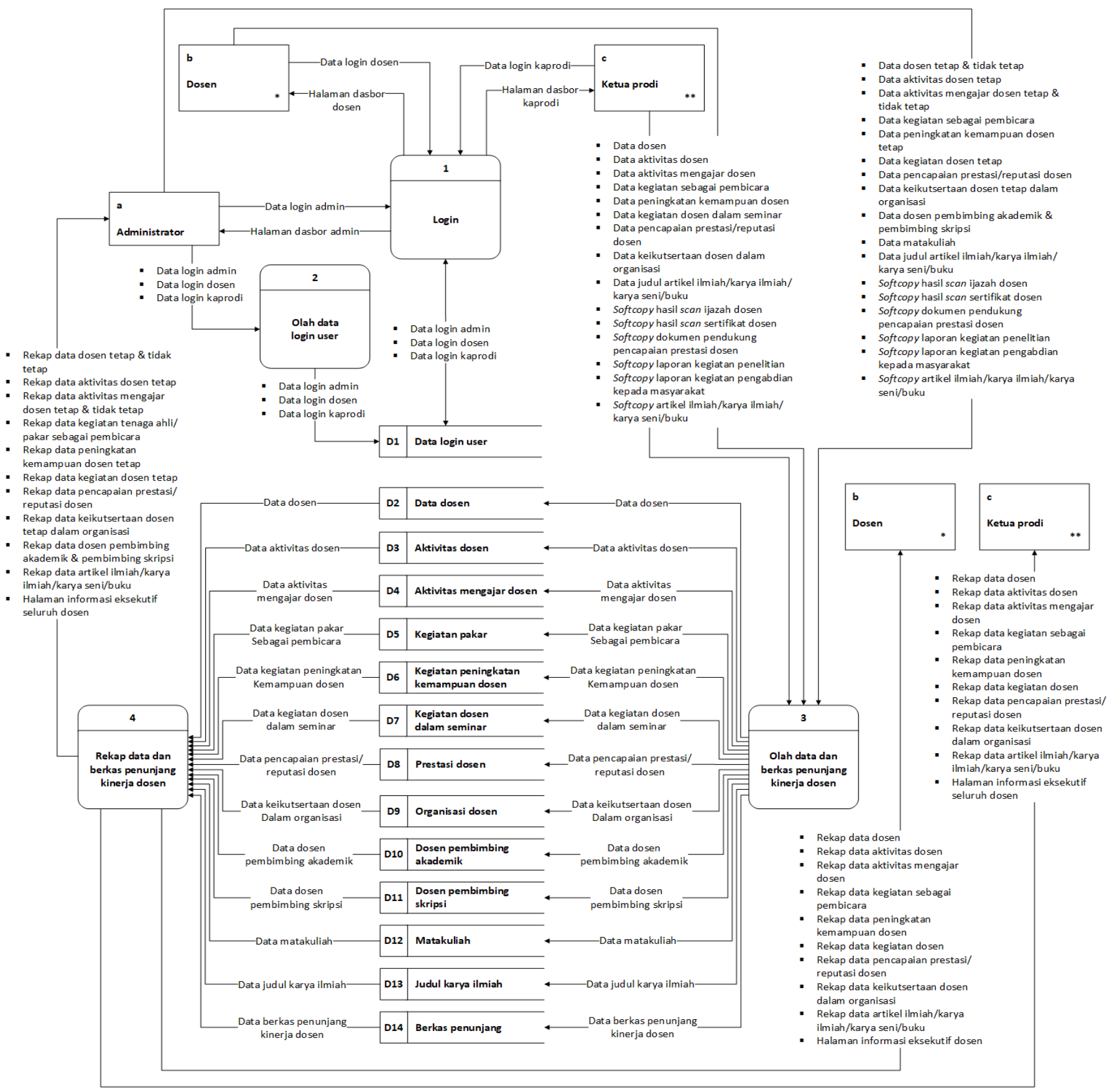

Gambar 2. DFD Level 0 Sistem 
Pada pembahasan ini, penulis hanya akan membahas tentang DFD Level 1 proses 1 dan proses 2 sebagaimana dapat dilihat pada Gambar 4 dan Gambar 5 berikut ini.

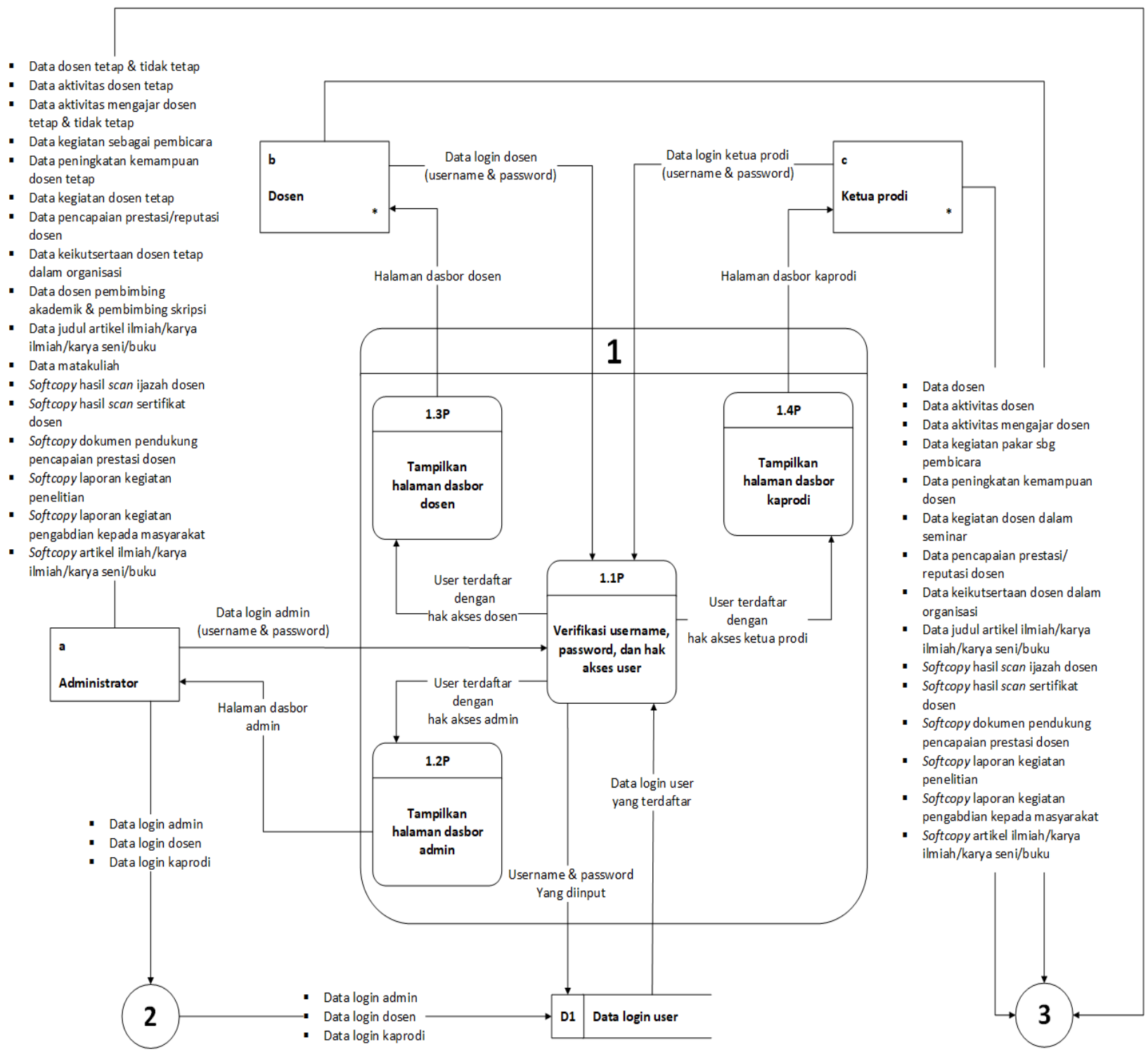

Gambar 3. DFD Level 1 Proses 1

Pada proses ini pengguna akan memasukkan data login berupa username dan password, akan tetapi setiap jenis pengguna memiliki level hak akses yang berbeda yaitu sebagai admin, dosen, atau ketua prodi. Jika pengguna memiliki hak akses sebagai administrator, maka data login pengguna akan diteruskan ke proses 1.2 (tampilkan halaman dasbor admin). Jika pengguna memiliki hak akses sebagai dosen, maka data login pengguna akan diteruskan ke proses 1.3 (tampilkan halaman dasbor dosen). Sedangkan jika pengguna memiliki hak akses sebagai ketua prodi, maka data login pengguna akan diteruskan ke proses 1.4 (tampilkan halaman dasbor kaprodi), dan pengguna bisa mengakses halaman dasbor khusus untuk ketua prodi. 


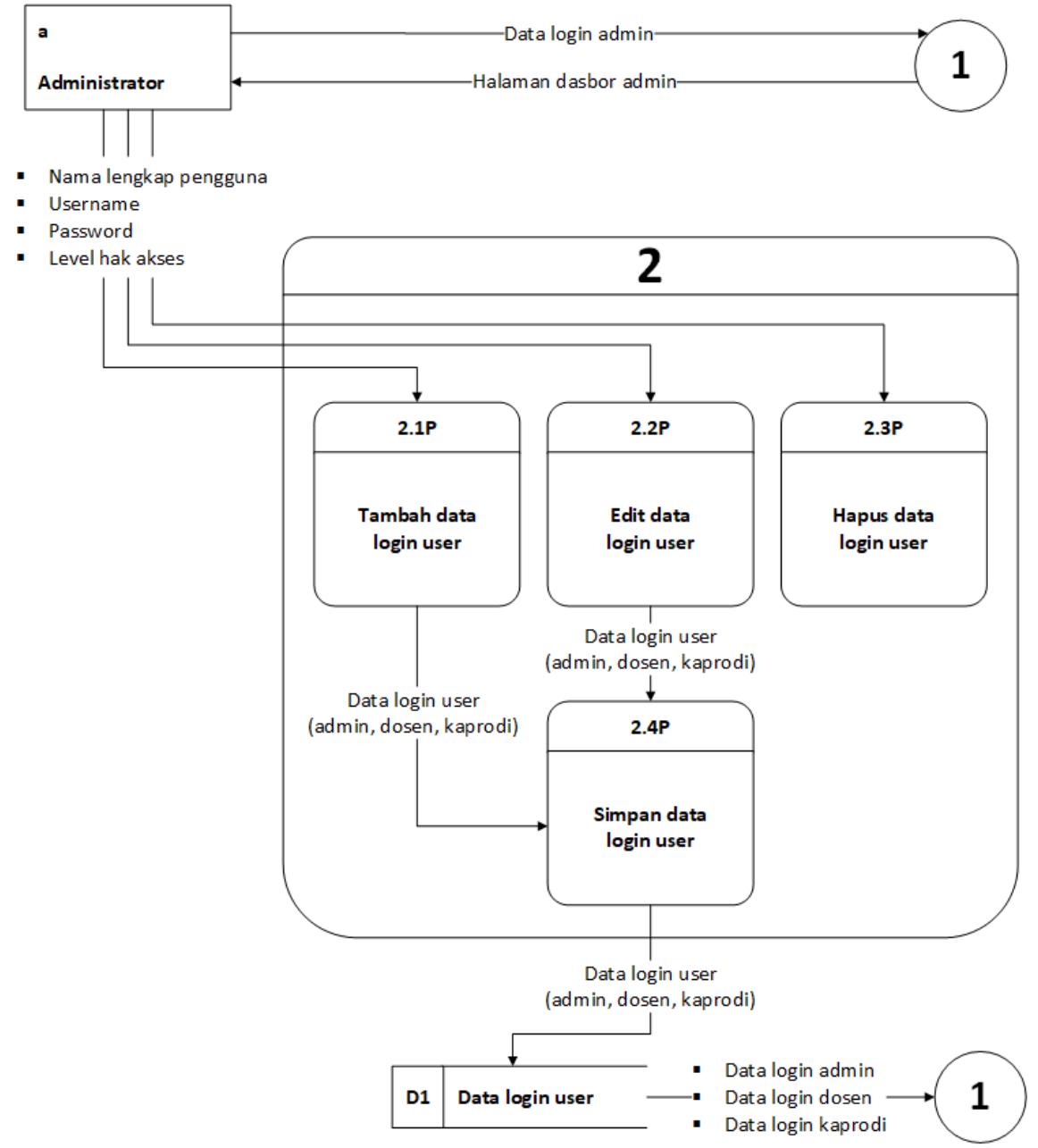

Gambar 4. DFD Level 1 Proses 2

Pada Gambar DFD Level 1 Proses 2, dapat diketahui bahwa proses ini hanya bisa dilakukan oleh pengguna dengan hak akses sebagai admin dimana admin bisa melakukan proses olah data login pengguna, baik dosen, ketua prodi maupun admin itu sendiri. Admin bisa menambahkan data login untuk pengguna baru, maupun mengedit dan menghapus data login pengguna yang telah terdaftar.

\section{PEMBAHASAN}

Perangkat lunak akan diimplementasikan dalam bentuk aplikasi web yang terdiri dari halaman login pengguna, halaman pengolahan data, dan halaman logout pengguna. Khusus untuk halaman pengolahan data akan memiliki tampilan dan fungsi yang berbeda sesuai dengan level akses pengguna yang mengaksesnya, yakni administrator, dosen dan ketua prodi (kaprodi).

1. Implementasi halaman login pengguna. Halaman login ini akan ditampilkan setiap kali pengguna ingin mengakses halaman pengolahan data. Pada halaman login ini pengguna harus memasukkan data berupa username dan password yang telah terdaftar.
Tampilan halaman login pengguna dapat dilihat pada Gambar 6 berikut:

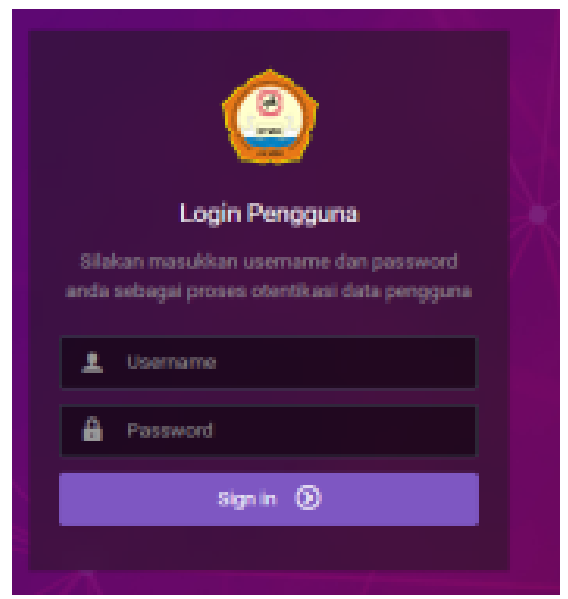

Gambar 5. Halaman Login Pengguna 
2. Implementasi halaman dashboard untuk admin. Halaman ini merupakan halaman utama yang ditampilkan kepada pengguna dengan level akses sebagai administrator. Halaman ini berisi data statistik terkait kinerja dosen secara keseluruhan. Tampilan halaman dashboard administrator dapat dilihat pada Gambar 7.

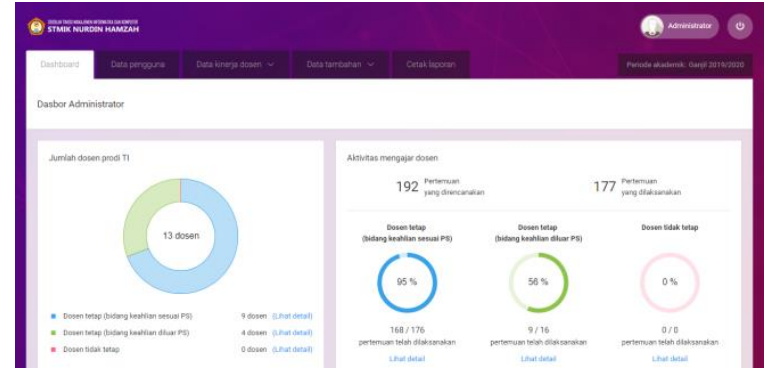

\section{Gambar 6. Halaman Dashboard Administrasi}

3. Implementasi halaman dashboard untuk dosen dan kaprodi. Halaman ini merupakan halaman utama yang ditampilkan kepada pengguna dengan level akses sebagai dosen atau kaprodi. Tampilan halaman dashboard dosen/kaprodi dapat dilihat pada Gambar 8.

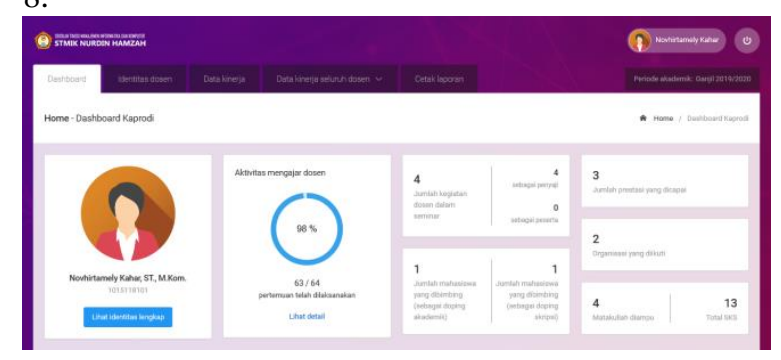

Gambar 7. Halaman Dashboard Dosen/Kaprodi

4. Implementasi halaman olah data pengguna. Halaman ini berfungsi untuk menampilkan, menambah, mengedit maupun menghapus data pengguna yang dapat mengakses aplikasi. Halaman olah data pengguna ini berisi tabel daftar data pengguna yang dilengkapi dengan tombol tambah data pengguna serta tombol opsi untuk mengedit dan menghapus data pengguna. Tampilan halaman olah data pengguna dapat dilihat pada Gambar 9.

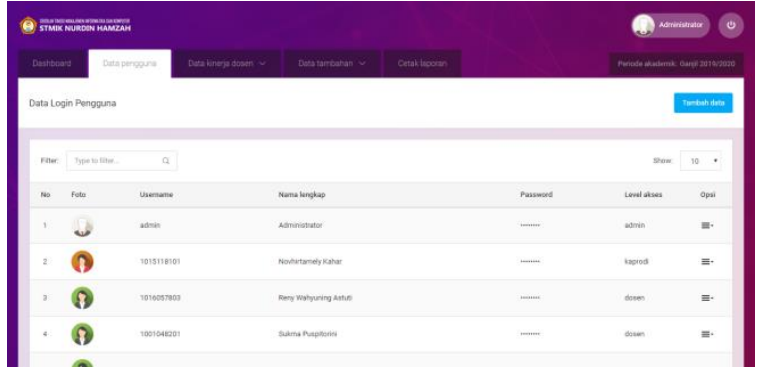

Gambar 8. Halaman Olah Data Pengguna

5. Implementasi halaman olah data kinerja dosen Halaman ini berfungsi untuk menampilkan, menambah, mengedit maupun menghapus data kinerja dosen. Halaman ini berisi tabel daftar data kinerja dosen yang dilengkapi dengan tombol tambah data serta tombol untuk mengedit dan menghapus data kinerja dosen. Tampilan halaman olah data kinerja dosen dapat dilihat pada Gambar 10 berikut:

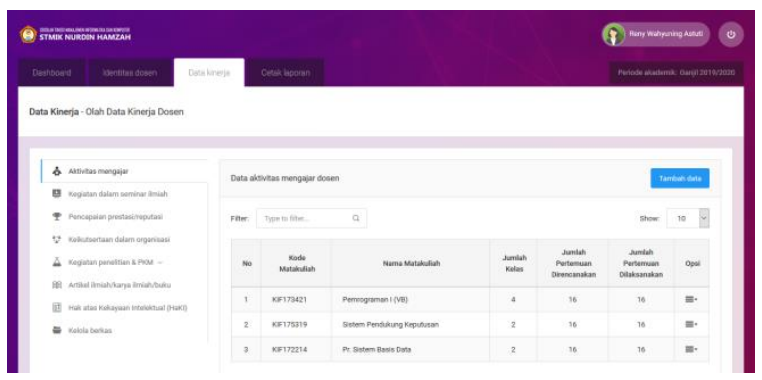

Gambar 9. Halaman Olah Data Kinerja Dosen

6. Implementasi halaman cetak laporan kinerja dosen. Halaman ini digunakan untuk membuat laporan kinerja dosen berdasarkan data-data kinerja dosen yang telah diinput sebelumnya. Laporan yang dihasilkan adalah laporan kinerja individual dosen dan dapat dibuat dalam bentuk dokumen PDF (format .pdf) atau file Excel (format .xls). Tampilan halaman cetak laporan kinerja dosen dapat dilihat pada Gambar 11 berikut:

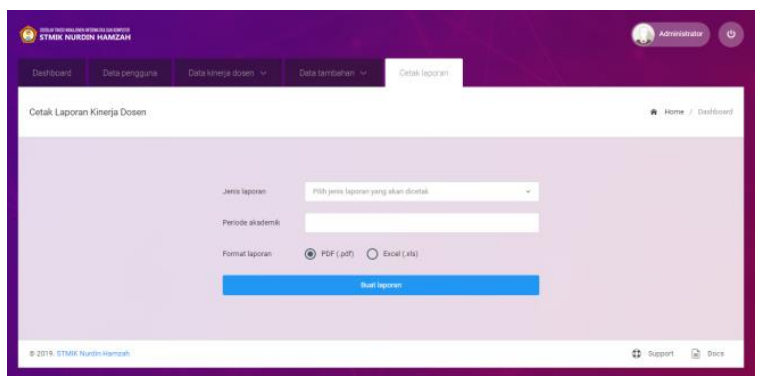

Gambar 10. Halaman Olah Data Kinerja Dosen

Laporan kinerja dosen berisi daftar data terkait kinerja dosen prodi TI yang disajikan dalam bentuk 
tabel yang disusun sesuai dengan format pada buku IIIA borang akreditasi prodi.

\section{KESIMPULAN}

Berdasarkan penelitian yang telah dilakukan dapat ditarik kesimpulan bahwa Sistem Informasi Eksekutif Pengolahan Data Kinerja dosen ini dapat diimplementasikan dengan baik dengan menggunakan bahasa pemrograman PHP, perangkat lunak manajemen basis data MySQL, serta framework CodeIgniter dan Bootstrap. Laporan kinerja dosen yang dihasilkan akan memiliki format yang sesuai dengan yang ada pada Buku IIIA Borang Akreditasi Prodi sehingga akan memudahkan pihak Prodi TI dalam melakukan penyusunan borang akreditasi Prodi.

\section{SARAN}

SIE yang dibangun masih memiliki beberapa kekurangan, antara lain sistem keamanan yang belum terlalu mumpuni hingga pengalaman penggunaan aplikasi yang belum sepenuhnya intuitif, sehingga kontribusi positif dari berbagai pihak sangat diharapkan dalam pengembangan aplikasi ini agar bisa dihasilkan sistem yang semakin baik dan optimal guna mempermudah proses pengolahan data kinerja dosen Prodi TI. Salah satu fitur yang dapat ditambahkan pada SIE ini adalah kemampuan untuk melakukan penyimpanan data maupun berkas di penyimpanan berbasis cloud agar keamanan data dan berkas yang tersimpan akan lebih terjaga.

\section{DAFTAR PUSTAKA}

Achmad, a.d., penggunaan data sistem informasi akademik (siak) dan sistem informasi penilaian angka kredit (pak) dari server database berbeda ke dalam sistem informasi eksekutif menggunakan metode web service. Jurnal it vol 9 no.3 desember 2018, hal 188-192. Tersedia melalui <https://lppmstmikhandayani.ac.id/index.php/jti/article/view/57/ 53> [diakses 7 november 2019].

Amin, a., puspitorini, s., dan purnama, f., sistem informasi alumni program studi teknik informatika stmik nurdin hamzah berbasis web. Jurnal fortech vol.01 no.02, november 2017.

Bakhri, s. Dan nuryamin, y,. 2018. Rancangan data warehouse untuk penunjang sistem informasi eksekutif pada yayasan ummu'l qurodi depok. Jurnal teknik komputer, vol.4 no.1 februari 2018. Tersedia melalui <http://ejournal.bsi.ac.id/ejurnal/index.php/jtk/articl e/view/2498/1917>. [diakses 21 oktober 2019].

Hutahaean, j., 2015, konsep sistem informasi, yogyakarta: deepublish.

Mahyuni, dkk., perancangan sistem pengolahan data pada sma negeri 6 kabupaten tebo. Jurnal ilmiah media sisfo, viii (3), 180-187

Mulia,m.t., komara, h., putra, s.i., mulyanto, f., dan subarkah, f., 2018. Pengembangan sistem informasi eksekutif dengan dukungan web service. Studi kasus: fakultas teknik unpas. Tersedia melalui < http://jurnal.atmaluhur.ac.id/index.php/knsi2018/art icle/view/453/378> [diakses 21 oktober 2019].

Permanasari, r., setyaningrum, r.m., dan sundari, s. 2014. Model hubungan kompetensi, profesionalisme dan kinerja dosen. Jurnal bisnis, manajemen \& perbankan vol. 1 no. 2 edisi september 2014:157174. Tersedia melalui < http://ojs.umsida.ac.id/index.php/jbmp/article/view/ 270/255> [diakses 19 oktober 2019]

Pradana, m., perencanaan skema sistem informasi untuk aktivitas manajemen. Jurnal ekombis review vol.4 no.1 tahun 2016. Tersedia melalui $<$ https://jurnal.unived.ac.id/index.php/er/article/vie w/155> [diakses 11 november 20019]

Sutabri, t., 2012, analisis sistem informasi, penerbit andi, yogyakarta

Widiastuti, n.i \& susanto, r. 2014. Kajian sistem monitoring dokumen akreditasi teknik informatika unikom. Majalah ilmiah unikom, vol. 12, no. 2, hh. 195-201. Tersedia melalui < https://jurnal.unikom.ac.id/_s/data/jurnal/volume12-2/07-miu-12-2-nely.pdf/pdf/07-miu-12-2nely.pdf>

\section{UCAPAN TERIMA KASIH}

Terima kasih kepada Prodi Teknik Informatika STMIK Nurdin Hamzah yang telah membantu dalam

pelaksanaan penelitian dari awal hingga pengujian sistem informasi eksekutif ini. Juga kepada STMIK Nurdin

Hamzah yang mensupport pengiriman makalah ini hingga dapat dipublish di Jurnal Sebatik 2019 